\title{
How groundwater interactions can influence UPSH (Underground Pumping Storage Hydroelectricity) operations
}

\author{
S. Bodeux, E. Pujades, P. Orban, S. Brouyère \& A. Dassargues \\ University of Liège, Hydrogeology \& Environmental Geology, Aquapole, ArGEnCo Dpt., Engineering \\ Faculty, Belgium
}

\section{ABSTRACT}

In the current energy grid, renewable energy has an increasing role to play. However, their intermittence cannot afford to regulate the produced electricity according to the irregular demand (Evans et al., 2012). Pumped Storage Hydroelectricity (PSH) is a well-known efficient technology to store and release electricity according to the demand needs but appropriate potential new sites are getting scarce (Steffen, 2012). An innovative alternative consists in using abandoned mines as lower reservoir of an Underground Pumping Storage Hydroelectricity (UPSH) plant (Fig. 1).

In such configuration, large amount of water will be pumped or injected in underground cavities, creating subsequently head oscillations in the surrounding aquifers. Consequently, this seepage occurring between the considered cavity and the varying groundwater heads in the surrounding geological medium may influence the efficiency of the UPSH plant but also the magnitude of the potential impacts on the groundwater resources.

A hybrid 3D finite element mixing cell method (Brouyère et al., 2009) is used to simulate numerically the use of a representative UPSH cavity and calculate the induced changes in groundwater heads in the surrounding geological medium. Different scenarios are computed varying parameter values (hydrogeological and lower reservoir characteristics), boundary conditions, and pumping/injection time-sequences.

By analyzing the computed piezometric heads at different distances from the underground reservoir, the magnitude of the aquifer response to pumping storage operations is assessed. The most expected and noticeable effect is the oscillation of groundwater levels. The existence a mean pseudo/ dynamic steady-state and the required time to reach it are also determined. The head difference and its time evolution between the cavity and the surrounding medium is triggering the leakage of groundwater into the cav- ity or the contrary. The resulting effects on the UPSH plant efficiency can be estimated.

Combining these outcomes, some feasibility criteria of this type of projects are identified. Going into practice, further models should include more in details local and specific geometrical and hydrogeological data of the considered old mine cavities used as lower reservoir. This kind of modelling approach can be used as a first approach for determining how the aquifer will response to short and long term changes in UPSH pumping/injection schemes.

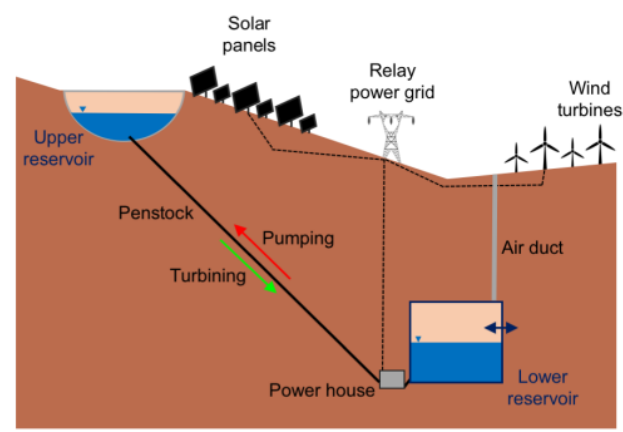

Figure 1. Schematic representation of an UPSH

\section{REFERENCES}

Bodeux S., Pujades E., Orban Ph. and Dassargues A., 2016, Mine as lower reservoir of an UPSH: groundwater impacts and feasibility, EGU2016, Vienna, April 17-22.

Brouyère S., Orban P., Wildemeersch S., Couturier J., Gardin, N. and A. Dassargues, 2009. The Hybrid Finite Element Mixing Cell method: A new flexible method for modeling mine ground water problems. Mine Water Environment, 28(2): 102-114.

Evans A., Strezov V. and Evans T.J., 2012. Assessment of utility energy storage options for increased renewable energy penetration. Renewable and Sustainable Energy Reviews, 16(6): 4141-4147.

Pujades E., Willems Th., Bodeux S. Orban Ph., Dassargues A. 2016, Underground Pumped Storage Hydroelectricity (UPSH) using abandoned works (deep mines or open pits): impacts on groundwater flow, Hydrogeology Journal, in press.

Steffen B., 2012. Prospects for pumped-hydro storage in Germany. Energy Policy, 45: 420-429. 